\title{
Enteric Methane Emissions and Rumen Fermentation Profile Treated by Dietary Chitosan: A Meta-Analysis of In Vitro Experiments
}

\author{
R. P. Harahap ${ }^{\mathrm{a}, \mathrm{c}}$, D. Setiawan ${ }^{\mathrm{a}}$, Nahrowi ${ }^{\mathrm{b}}$, S. Suharti ${ }^{\mathrm{b}}$, T. Obitsu ${ }^{\mathrm{d}}$, \& A. Jayanegara ${ }^{\mathrm{b}, *}$ \\ aStudy Program of Animal Science, Faculty of Agriculture, Tanjungpura University, \\ Jalan Prof. Dr. H. Hadari Nawawi, Pontianak 78124, Indonesia \\ ${ }^{\text {bDepartment }}$ of Nutrition and Feed Technology, Faculty of Animal Science, IPB University \\ (Bogor Agricultural University), \\ ${ }^{\mathrm{c}}$ Graduate School of Nutrition and Feed Science, Faculty of Animal Science, IPB University \\ (Bogor Agricultural University), \\ Jalan Agatis Kampus IPB Dramaga, Bogor 16680, Indonesia \\ dGraduate School of Integrated Sciences for Life, Hiroshima University, \\ 1-4-4 Kagamiyama, Higashihiroshima, 739-8528, Japan \\ *Corresponding author: anuraga.jayanegara@gmail.com \\ (Received 26-03-2020; Revised 30-04-2020; Accepted 11-05-2020)
}

\begin{abstract}
Chitosan is a natural compound obtained from deacetylation of chitin, which is a biopolymer present in the exoskeleton of crustaceans such as crabs and shrimp. The present study aimed to perform a meta-analysis from published studies regarding the effects of chitosan on methane emission and rumen fermentation profile of in vitro batch culture experiments. A total of 41 studies from 12 articles were integrated into a database. Parameters included were gas production, methane emission, rumen fermentation characteristics, microbial population, nutrient digestibility, and fatty acid profile. Data were analyzed according to mixed model methodology in which different studies were treated as random effects and chitosan addition levels were treated as fixed effects. Results showed that chitosan addition was able to reduce enteric methane emissions $(p<0.001)$. Such methane decrease was accompanied by a decline in the protozoa population $(p<0.05)$ and a tendency of methanogen reduction $(p<0.1)$. The increasing chitosan level was associated with a decrease in total VFA and ammonia concentrations (both at $\mathrm{p}<0.001)$. Chitosan addition decreased acetate proportion $(\mathrm{p}<0.001)$ while elevated propionate proportion $(\mathrm{p}<0.001)$. Chitosan was associated with an increase of dry matter digestibility, crude protein digestibility, and neutral detergent fiber digestibility $(\mathrm{p}<0.001)$. Chitosan increased concentrations of $\mathrm{C}_{18: 3 n 3}(\mathrm{p}<0.05)$, conjugated linoleic acid $(\mathrm{p}<0.01)$ and polyunsaturated fatty acids $(\mathrm{p}<0.01)$ while decreased concentration of saturated fatty acids $(\mathrm{p}<0.001)$. It can be concluded that chitosan addition can mitigate enteric methane emission and alters rumen fermentation profiles in a favorable direction.
\end{abstract}

Keywords: chitosan; additive; methanogenesis; rumen; meta-analysis

\section{INTRODUCTION}

Methane is a greenhouse gas that has more significant impact than carbon dioxide with regard to its ability to retain heat. Methane production from ruminant livestock is originated from synthesis during fermentation of feed in the rumen, which responsible for about $5 \%$ to $7 \%$ of feed gross energy (Hristov et al., 2013). Thus, an approach of inhibiting $\mathrm{CH}_{4}$ production in ruminants is considered to provide efficient use of feed energy, economic benefits, and reduce the effects of global greenhouse gases (Kaharabata et al., 2015). Inhibition of $\mathrm{CH}_{4}$ production in ruminants can be done by manipulating the rumen ecosystem. Several types of natural compounds that have antimicrobial properties can be used to manipulate the rumen microbial ecosystem. Some chemical feed additives, antibiotics, methane inhibitors, defaunation agents, and extracts from plants have been shown to increase rumen metabolism and growth of ruminant animals (Patra \& Saxena, 2011; Jayanegara et al., 2018a). However, chemical feed additives have been concerned about the presence of chemical residues in livestock products, the development of bacterial resistance to antibiotics and excessive toxicity, and the cost of some plant extracts that limited their use in ruminant diets (Wina et al., 2005). As a result, ruminant nutrition scientists are still actively looking for alternative feed additives that can improve rumen function. One type of natural compound that has antimicrobial properties and has the potential to be used to manipulate rumen microbial ecosystems is chitosan.

Chitosan may be obtained from deacetylation of chitin, which is a biopolymer present in the exoskeleton of crustaceans such as crabs and shrimp. Chitosan is very interesting to study because it can change the profile of volatile fatty acids (VFA) by increasing propionate concentration $\left(\mathrm{C}_{3}\right)$ and thereby reducing the production of $\mathrm{CH}_{4}$ (Haryati et al., 2019). Furthermore, the reduction in $\mathrm{CH}_{4}$ is related to the degree of deacetylation found in chitosan, which can modify the cell wall permeability of 
methanogenic archaea (Zanferari et al., 2018). Previous studies have shown that the addition of chitosan can inhibit the synthesis of $\mathrm{CH}_{4}$ in vitro when it is added to substrates at high concentrations (Goiri et al., 2009a). Furthermore, the addition of chitosan source from black soldier flies at a concentration of $2 \%$ of the substrate results in a sharp reduction effect on $\mathrm{CH}_{4}$ emissions (Haryati et al., 2019). Although there have been a number of studies evaluating chitosan effects on rumen fermentation, to date, there is no study attempting to quantitatively summarize the effects by employing a meta-analysis approach.

This present study, therefore, aimed to perform a meta-analysis from published experiments regarding the effect of chitosan on methane emissions and rumen fermentation using in vitro batch culture experiments. All related parameters such as total gas, methane production, in vitro digestibility, rumen fermentation characteristics, rumen microbial profile, carboxymethyl cellulase (CMCase) enzyme activity, and rumen fatty acid profile were also evaluated to comprehensively assess the effect of chitosan on the rumen in vitro batch culture experiments.

\section{MATERIALS AND METHODS}

\section{Database Development}

The database was developed from studies reporting the use of chitosan to reduce enteric methane emissions from ruminants. Inclusion criteria for an article entered into the database were: (1) the article was published in English, (2) the concentration of chitosan in diet and $\mathrm{CH}_{4}$ emissions were specified, and (3) the experiment was carried out by using in vitro batch culture systems with cattle or sheep as rumen fluid donors. A total of 41 studies from 12 articles were finally integrated into the database, as described in Table 1.

The parameters tabulated in this study were total gas production, methane production, $\mathrm{H}_{2} \mathrm{~S}$ production, rumen fermentation characteristics, rumen microbial profile, CMCase enzyme activity, in vitro digestibility, and rumen fatty acid profile. The in vitro digestibility parameters were dry matter (DM) digestibility, organic matter (OM) digestibility, crude protein $(\mathrm{CP})$ digestibility, and neutral detergent fiber (NDF) digestibility. The characteristics of rumen fermentation in vitro included

Table 1. In vitro batch culture experiments (Expt) included in the meta-analysis of the effect of chitosan levels (g/kg DM) on rumen fermentation and methane emissions

\begin{tabular}{|c|c|c|c|c|c|c|c|}
\hline Expt no. & Reference & Basal feed & Chitosan source & $\begin{array}{l}\text { Deacetylation } \\
\text { degree }(\%)\end{array}$ & $\begin{array}{l}\text { Chitosan level } \\
(\mathrm{g} / \mathrm{kg} \mathrm{DM})\end{array}$ & $\begin{array}{l}\text { Gas sam- } \\
\text { pling* (h) }\end{array}$ & $\begin{array}{c}\mathrm{CH}_{4} \\
\text { method }\end{array}$ \\
\hline \multirow[t]{6}{*}{1} & \multirow[t]{6}{*}{ (Goiri et al., 2009a) } & \multirow[t]{6}{*}{ Maize silage } & Biolog, S:A & 75 & \multirow[t]{6}{*}{0 and 0.75} & \multirow[t]{6}{*}{12} & \multirow[t]{6}{*}{ GC } \\
\hline & & & Biolog, S:A & 85 & & & \\
\hline & & & Biolog, S:A & 85 & & & \\
\hline & & & Biolog, S:A & 85 & & & \\
\hline & & & FMC Biopolymer As & $75-90$ & & & \\
\hline & & & Trades S.A. & $>95$ & & & \\
\hline \multirow[t]{3}{*}{2} & \multirow[t]{3}{*}{ (Goiri et al., 2009b) } & \multirow{3}{*}{$\begin{array}{l}\text { Alfalfa hay and } \\
\text { concentrate } \\
(80: 20,50: 50 \text {, and } 20: 80)\end{array}$} & Biolog, S:A & 75 & \multirow[t]{3}{*}{$0-1.5$} & \multirow[t]{3}{*}{12} & \multirow[t]{3}{*}{ GC } \\
\hline & & & Biolog, S:A & 85 & & & \\
\hline & & & Trades S.A. & $>95$ & & & \\
\hline 3 & $\begin{array}{l}\text { (Goiri \& Oregui, } \\
\text { 2014) }\end{array}$ & $\begin{array}{l}\text { Alfalfa hay and concen- } \\
\text { trate }(50: 50)\end{array}$ & Trades S.A. & $>95$ & $0-5.96$ & 12 & GC \\
\hline 4 & (Li et al., 2013) & $\begin{array}{l}\text { Alfalfa hay and } \\
\text { concentrate } \\
(80: 20,50: 50 \text { and } 20: 80)\end{array}$ & $\begin{array}{l}\text { Sigma-Aldrich, USA } \\
\text { (Shrimp shell) }\end{array}$ & $\geq 75$ & $0-1$ & 24 & GC \\
\hline \multirow[t]{2}{*}{5} & \multirow[t]{2}{*}{$\begin{array}{l}\text { (Wencelová et al., } \\
\text { 2013) }\end{array}$} & $\begin{array}{l}\text { Meadow hay and barley } \\
\text { grain (80:20 and 50:50) }\end{array}$ & \multirow[t]{2}{*}{$\begin{array}{l}\text { Sigma-Aldrich Co., St. } \\
\text { Louis, MO, USA }\end{array}$} & \multirow[t]{2}{*}{ Not specified } & \multirow[t]{2}{*}{$0-0.1$} & \multirow[t]{2}{*}{24} & \multirow[t]{2}{*}{ GC } \\
\hline & & Maize silage & & & & & \\
\hline 6 & (Henry et al., 2015) & Concentrate & $\begin{array}{l}\text { Pharma Nutrients, Inc., } \\
\text { Lake Forest, IL }\end{array}$ & 90 & $0-10$ & 24 & GC \\
\hline 7 & $\begin{array}{l}\text { (Gandra et al., } \\
\text { 2016) }\end{array}$ & Sugarcane silage & $\begin{array}{l}\text { Polymar Industria, Ceara, } \\
\text { Brazil }\end{array}$ & 95 & 0 and 36.36 & $\begin{array}{c}\text { Not } \\
\text { specified }\end{array}$ & $\begin{array}{c}\text { Not } \\
\text { specified }\end{array}$ \\
\hline \multirow[t]{2}{*}{8} & \multirow[t]{2}{*}{$\begin{array}{l}\text { (Belanche et al., } \\
\text { 2016a) }\end{array}$} & \multirow[t]{2}{*}{ Mixed diet } & $\begin{array}{l}\text { Insoluble chitosan and } \\
\text { soluble chitosan }\end{array}$ & 80 & \multirow[t]{2}{*}{$0-2$} & \multirow[t]{2}{*}{24} & \multirow[t]{2}{*}{ GC } \\
\hline & & & $\begin{array}{l}\text { Nitta Gelatin India Ltd, } \\
\text { Cocin, Kerala, India }\end{array}$ & $>85$ & & & \\
\hline 9 & $\begin{array}{l}\text { (Gandra et al., } \\
\text { 2018) }\end{array}$ & $\begin{array}{l}\text { Soybean whole-plant } \\
\text { silage }\end{array}$ & $\begin{array}{l}\text { Polymar Industria e Cia. } \\
\text { Imp. And Exp. LTDA, } \\
\text { Fortaleza, Brazil }\end{array}$ & 95 & 0 and 14.62 & $\begin{array}{c}\text { Not } \\
\text { specified }\end{array}$ & $\begin{array}{c}\text { Not } \\
\text { specified }\end{array}$ \\
\hline 10 & $\begin{array}{l}\text { (Haryati et al., } \\
\text { 2019) }\end{array}$ & $\begin{array}{l}\text { Setaria splendida grass } \\
\text { and concentrate }\end{array}$ & $\begin{array}{l}\text { Black soldier fly (Heredia } \\
\text { illucens) }\end{array}$ & $>61$ & $0-20$ & 24 & GC \\
\hline 11 & (Pereira et al., 2019) & $\begin{array}{l}\text { Hay forage and concen- } \\
\text { trate }(100: 0,50: 50,40: 60 \text {, } \\
\text { and } 20: 80)\end{array}$ & Not specified & $>85$ & 0 and 0.90 & $\begin{array}{c}\text { Not } \\
\text { specified }\end{array}$ & $\begin{array}{c}\text { Not } \\
\text { specified }\end{array}$ \\
\hline 12 & $\begin{array}{l}\text { (Seankamsorn et } \\
\text { al., 2019) }\end{array}$ & Total mixed ration & Shrimp shell & 88 & $0-20$ & 4 & GC \\
\hline
\end{tabular}

Note: GC=gas chromatograph; DM=dry matter. ${ }^{*}=$ Time of incubation when the gas was sampled for $\mathrm{CH} 4$ measurement. 
were $\mathrm{pH}$, total volatile fatty acids, the molar percentage of acetic $\left(\mathrm{C}_{2}\right)$, propionic $\left(\mathrm{C}_{3}\right)$, butyric $\left(\mathrm{C}_{4}\right)$, isobutyric (iso- $\mathrm{C}_{4}$ ), valeric $\left(\mathrm{C}_{5}\right)$, isovaleric (iso- $\mathrm{C} 5$ ), and caproic $\left(\mathrm{C}_{6}\right)$ acids in total VFA, the ratio of $\mathrm{C}_{2}$ to $\mathrm{C}_{3}$, branch-chained volatile fatty acids (BCVFA) molar proportions, and total VFA to truly degraded substrate (TVFA:TDS) and ammonia concentration $\left(\mathrm{NH}_{3}\right)$. The in vitro rumen microbial parameters included were total bacteria, protozoa, Fibrobacter succinogenes, methanogen, and general anaerobic fungi. The fatty acid profile parameters included were $\mathrm{C}_{14: 0^{\prime}} \mathrm{C}_{15: 0^{\prime}} \mathrm{C}_{16: 0^{\prime}} \mathrm{C}_{17: 0^{\prime}} \mathrm{C}_{18: 0^{\prime}} \mathrm{C}_{18: 2 \mathrm{n} 6^{\prime}}$ CLA, $\mathrm{C}_{18: 3 \mathrm{n} 3^{\prime}}$ saturated fatty acids (SFA), monounsaturated fatty acids (MUFA), and polyunsaturated fatty acids (PUFA).

\section{Statistical Analysis}

A meta-analysis of data was performed by using mixed model methodology according to St-Pierre (2001), in which different studies in the database were treated as random effects whereas chitosan addition levels in diets were treated as fixed effects. The number of publications included in the database reflected the population of such an in vitro batch study on chitosan addition from all periods. The mixed model procedure was employed with the following model:

$$
\mathrm{Y}_{\mathrm{ij}}=\mathrm{B}_{0}+\mathrm{B}_{1} \mathrm{X}_{\mathrm{ij}}+\mathrm{s}_{\mathrm{i}}+\mathrm{e}_{\mathrm{ij}}
$$

where $Y_{i j}$ was the dependent variable, $B_{0}$ was overall intercept across all experiments (fixed effect), $B_{1}$ was linear regression coefficient of $Y$ on $X$ (fixed effect), $X_{i j}$ was the value of the continuous predictor variable (chitosan addition level), $s_{i}$ was random effect of experiment $i$, and $e_{i j}$ was the unexplained residual error. The variable of the experiment was declared in the class statement as it did not contain any quantitative information. Besides, the regression equations were also presented with $p$-value and root mean square error (RMSE). The statistical analysis was performed in SAS software version 9.1 (SAS Institute Inc., Cary, NC, USA) by using mixed procedure (PROC MIXED).

\section{RESULTS}

\section{Total Gas, Methane, and $\mathrm{H}_{2} \mathrm{~S}$ Production}

The effects of chitosan addition on total gas, methane, and $\mathrm{H}_{2} \mathrm{~S}$ production in vitro batch culture study are shown in Table 2. An increase in the chitosan addition level was associated with a decrease in total gas production $(p<0.001)$. Further, chitosan addition decreased enteric $\mathrm{CH}_{4}$ emissions, both when expressed as $\mathrm{CH}_{4} /$ day and $\mathrm{CH}_{4} / \mathrm{DOM}(\mathrm{p}<0.001)$. However, increasing the chitosan addition level did not alter $\mathrm{H}_{2} \mathrm{~S}$ production.

\section{Rumen Fermentation, Microbial Population, and CMCase Activity}

The effects of chitosan addition on rumen fermentation, microbial population, and CMCase activity in the in vitro batch culture study are presented in Table 3 . The addition of chitosan increased rumen $\mathrm{pH}(\mathrm{p}<0.001)$ but decreased total VFA concentration $(\mathrm{p}<0.001)$. Rumen $\mathrm{NH}_{3}$ concentration decreased due to chitosan addition $(\mathrm{p}<0.001)$. Concerning VFA composition, the proportions of $C_{2}$ and $C_{4}$ decreased due to the addition of chitosan $(p<0.001)$. Similarly, the ratio of $C_{2}$ to $C_{3}$ and BCVFA decreased due to chitosan addition $(p<0.001)$. On the contrary, the proportions of $\mathrm{C}_{3^{\prime}}$ iso- $\mathrm{C}_{4^{\prime}}, \mathrm{C}_{5}$, and iso- $\mathrm{C}_{5}$ increased $(p<0.001)$ due to the addition of chitosan, but $C_{6}$ was unchanged. Chitosan addition resulted in an increase of TVFA:TDS ratio $(\mathrm{p}<0.001)$. The addition of chitosan reduced the protozoa population $(\mathrm{p}<0.05)$ but increased the total bacteria $(p<0.01)$. Further, the addition of chitosan tended to reduce archaea methanogen $(p<0.1)$ but did not change the populations of Fibrobacter succinogenes and anaerobic fungi. The addition of chitosan decreased CMCase enzyme activity $(\mathrm{p}<0.05)$.

\section{In Vitro Digestibility}

The effect of chitosan addition on nutrient digestibility in the in vitro batch culture study is shown in Table 4. The increasing level of chitosan was associated with increasing dry matter digestibility (DMD) $(\mathrm{P}<0.001)$, crude protein digestibility $(\mathrm{CPD})(\mathrm{P}<0.01)$, and neutral detergent fiber digestibility (NDFD) $(\mathrm{P}<0.001)$.

\section{Rumen Fatty Acid Profile}

The effect of chitosan addition on rumen fatty acid profile is presented in Table 5. The addition of chitosan was associated with decreasing concentrations of C14:0, C15:0, C16:0, C17:0, C18:0, and lower saturated fatty acid (SFA) $(p<0.01)$, but increasing concentrations of $\mathrm{C} 18: 2 \mathrm{n} 6$ and $\mathrm{C} 18: 3 \mathrm{n} 3(\mathrm{p}<0.05)$. Concentrations of cis9, trans11 C18:2, the main isomer of conjugated linoleic acid (CLA) in the rumen, monounsaturated fatty acids (MUFA), and polyunsaturated fatty acids (PUFA) increased with increasing level of chitosan addition $(\mathrm{p}<0.01)$

Table 2. Gas production and enteric methane $\left(\mathrm{CH}_{4}\right)$ emission of in vitro batch culture study treated by chitosan addition (in $\left.\mathrm{g} / \mathrm{kg} \mathrm{DM}\right)$

\begin{tabular}{|c|c|c|c|c|c|c|c|c|}
\hline \multirow{2}{*}{$\begin{array}{l}\text { Response } \\
\text { parameter }\end{array}$} & \multirow{2}{*}{ Unit } & \multirow{2}{*}{$\mathrm{n}$} & \multicolumn{4}{|c|}{ Parameter estimates } & \multicolumn{2}{|c|}{ Model statistics } \\
\hline & & & Intercept & SE intercept & Slope & SE slope & p-Value & RMSE \\
\hline Gas production & $\mathrm{mL} / \mathrm{g} \mathrm{DM}$ & 42 & 199.1 & 15.2 & -0.657 & 0.695 & $<.001$ & 28.9 \\
\hline $\mathrm{CH}_{4}$ & $\mathrm{mmol} / \mathrm{d}$ & 65 & 1.03 & 0.13 & -0.072 & 0.017 & $<.001$ & 0.17 \\
\hline $\mathrm{CH}_{4}$ & $\mathrm{mmol} / \mathrm{g} \mathrm{DOM}$ & 47 & 3.58 & 0.41 & -0.050 & 0.055 & $<.001$ & 1.76 \\
\hline $\mathrm{H}_{2} \mathrm{~S}$ & $\mu \mathrm{mol} / \mathrm{d} / \mathrm{g} \mathrm{DM}$ & 6 & 5.55 & 3.72 & 0.121 & 0.046 & 0.376 & 0.79 \\
\hline
\end{tabular}

Note: $\mathrm{DM}=$ dry matter; $\mathrm{DOM}=$ digested organic matter; $\mathrm{n}=$ number of treatment; $\mathrm{RMSE}=$ residual mean square error; $\mathrm{SE}=$ standard error 
Table 3. Rumen fermentation, microbial population, and enzyme CMCase activity in the in vitro batch culture study treated by chitosan addition (in $\mathrm{g} / \mathrm{kg} \mathrm{DM}$ )

\begin{tabular}{|c|c|c|c|c|c|c|c|c|}
\hline \multirow{2}{*}{ Response parameter } & \multirow{2}{*}{ Unit } & \multirow{2}{*}{$\mathrm{n}$} & \multicolumn{4}{|c|}{ Parameter estimates } & \multicolumn{2}{|c|}{ Model statistics } \\
\hline & & & Intercept & SE intercept & Slope & SE slope & p-Value & RMSE \\
\hline $\mathrm{pH}$ & & 82 & 6.40 & 0.05 & 0.002 & 0.004 & $<.001$ & 0.12 \\
\hline $\mathrm{NH}_{3}$ & $\mathrm{mg} / \mathrm{dL}$ & 82 & 25.2 & 1.43 & -0.044 & 0.243 & $<.001$ & 8.24 \\
\hline Total VFA & $\mathrm{mmol} / \mathrm{L}$ & 89 & 67.8 & 3.19 & -0.228 & 0.366 & $<.001$ & 7.49 \\
\hline $\mathrm{C}_{2}$ & $\%$ & 92 & 62.7 & 0.98 & -0.024 & 0.071 & $<.001$ & 2.29 \\
\hline $\mathrm{C}_{3}$ & $\%$ & 92 & 20.4 & 0.68 & 0.304 & 0.155 & $<.001$ & 5.42 \\
\hline $\mathrm{C}_{4}$ & $\%$ & 94 & 11.5 & 0.47 & -0.199 & 0.086 & $<.001$ & 2.97 \\
\hline iso- $\mathrm{C}_{4}$ & $\%$ & 25 & 0.95 & 0.16 & 0.001 & 0.004 & $<.001$ & 0.07 \\
\hline $\mathrm{C}_{5}$ & $\%$ & 27 & 2.13 & 0.17 & 0.016 & 0.009 & $<.001$ & 0.17 \\
\hline iso- $\mathrm{C}_{5}$ & $\%$ & 25 & 1.86 & 0.33 & 0.003 & 0.011 & $<.001$ & 0.20 \\
\hline $\mathrm{C}_{6}$ & $\%$ & 6 & 0.20 & 0.22 & 0.004 & 0.002 & 0.527 & 0.04 \\
\hline $\mathrm{C}_{2}: \mathrm{C}_{3}$ & & 92 & 3.23 & 0.14 & -0.041 & 0.024 & $<.001$ & 0.81 \\
\hline BCVFA & & 25 & 3.39 & 0.44 & -0.314 & 0.082 & $<.001$ & 0.87 \\
\hline TVFA:TDS & $\mathrm{mmol} / \mathrm{g} \mathrm{DM}$ & 36 & 8.75 & 0.53 & 1.80 & 0.227 & $<.001$ & 1.33 \\
\hline Bacteria & $\times 10^{10} / \mathrm{g}$ & 12 & 0.98 & 0.06 & 0.018 & 0.050 & 0.004 & 0.13 \\
\hline Methanogen & $\times 10^{3} / \mathrm{g}$ & 12 & 3.86 & 1.12 & -2.76 & 1.475 & 0.075 & 3.81 \\
\hline Fibrobacter succinogenes & $\times 10^{3} / \mathrm{g}$ & 12 & 2.26 & 1.50 & 6.20 & 1.849 & 0.272 & 4.77 \\
\hline Anaerobic fungi & $\times 10^{3} / \mathrm{g}$ & 12 & 1.86 & 0.84 & 0.014 & 0.303 & 0.158 & 0.78 \\
\hline Protozoa & $\times 10^{2} / \mathrm{g}$ & 12 & 4.96 & 0.87 & -0.636 & 0.821 & 0.030 & 2.12 \\
\hline CMCase & $\mathrm{U} / \mathrm{mL}$ & 12 & 0.56 & 0.10 & -0.107 & 0.033 & 0.030 & 0.09 \\
\hline
\end{tabular}

Note: $C_{2}=$ acetate; $C_{3}=$ propionate; $C_{4}=$ butyrate; $C_{5}=$ valerate; $C_{6}=$ caproate; $\mathrm{NH}_{3}=$ ammonia; $D M=$ dry matter; $n=$ number of treatment; $B C V F A=$ branchchain volatile fatty acids; TVAS:TDS= total VFA-to-truly degraded substrate rasio; RMSE= residual mean square error; $\mathrm{SE}=$ standard error.

Table 4. Nutrient digestibility in the in vitro batch culture study treated by chitosan addition (in $\mathrm{g} / \mathrm{kg} \mathrm{DM}$ )

\begin{tabular}{|c|c|c|c|c|c|c|c|c|}
\hline \multirow{2}{*}{ Response parameter } & \multirow{2}{*}{ Unit } & \multirow{2}{*}{$\mathrm{n}$} & \multicolumn{4}{|c|}{ Parameter estimates } & \multicolumn{2}{|c|}{ Model statistics } \\
\hline & & & Intercept & SE intercept & Slope & SE slope & p-Value & RMSE \\
\hline DMD & $\mathrm{g} / \mathrm{kg}$ & 51 & 651 & 24.2 & 0.966 & 0.971 & $<.001$ & 71.6 \\
\hline CPD & $\mathrm{g} / \mathrm{kg}$ & 10 & 503 & 95.2 & 3.60 & 2.999 & 0.006 & 98.7 \\
\hline NDFD & $\mathrm{g} / \mathrm{kg}$ & 15 & 601 & 15.0 & 1.98 & 0.955 & $<.001$ & 73.9 \\
\hline
\end{tabular}

Note: $\mathrm{DMD}=$ dry matter digestibility; $\mathrm{OMD}=$ organic matter digestibility; $\mathrm{CPD}=$ crude protein digestibility; NDFD= neutral detergent fiber digestibility; $\mathrm{n}=$ number of treatment; $\mathrm{SE}=$ standard error; $\mathrm{RMSE}=$ residual mean square error.

\section{DISCUSSION}

The in vitro rumen fermentation process produces total gas in the form of $\mathrm{CO}_{2}, \mathrm{CH}_{4^{\prime}}$ and small amounts of $\mathrm{H}_{2}, \mathrm{~N}_{2}$, and $\mathrm{O}_{2}$. Total gas is produced from degradation and fermentation of substrate through the action of rumen microbes. Among the macromolecules, carbohydrate is the primary nutrient that contributes significantly to total gas production as compared to protein (Jayanegara et al., 2018b). In this study, the addition of chitosan can reduce total gas production and methane emission, but it has no effect on $\mathrm{H}_{2} \mathrm{~S}$ production. This study was in agreement with previous research which reported that increasing level of chitosan was associated with a decrease in total gas production (Li et al., 2013; Wencelová et al., 2013; Henry et al., 2015; Haryati et al., 2019), but different from other reports stating that the addition of chitosan level did not affect the accumulation of gas production in an in vitro batch culture (Seankamsorn et al., 2019; Belanche et al., 2016a). A number of studies observed that dietary chitosan could reduce methane emission in the in vitro rumen fermen- tation system (Belanche et al., 2016a; Goiri et al., 2009a; Goiri et al., 2009b; Goiri \& Oregui, 2014; Seankamsorn et al., 2019; Haryati et al., 2019; Henry et al., 2015; Li et al., 2013), which were in agreement with the present metaanalysis. In this study, increasing the chitosan level did not affect $\mathrm{H}_{2} \mathrm{~S}$ production, but in a previous study reported that chitosan increased $\mathrm{H}_{2} \mathrm{~S}$ production in low concentrate substrate under in vitro rumen environment (Henry et al., 2015).

Chitosan is a natural, non-toxic, and biodegradable biopolymer that commonly used as a broad-spectrum antimicrobial component (Kong et al., 2010; Vendramini et al., 2016). The decrease in methane production can be caused by inhibition of methanogenesis by decreasing the use of $\mathrm{H}_{2}$ as a substrate for $\mathrm{CH}_{4}$ formation (Janssen, 2010). Furthermore, chitosan is likely to reduce methanogenic archaea, the main microbial group responsible for methane formation. Another plausible explanation regarding such lower methanogenesis due to chitosan addition is through the reduction of the protozoa population, particularly the Entodinium spp. (Wencelová et al., 2013). A certain number of methanogen lives symbi- 
Table 5. Rumen fatty acid profile in the in vitro batch culture study treated by chitosan addition (in g/kg DM)

\begin{tabular}{|c|c|c|c|c|c|c|c|c|}
\hline \multirow{2}{*}{$\begin{array}{l}\text { Response } \\
\text { parameter }\end{array}$} & \multirow{2}{*}{ Unit } & \multirow{2}{*}{$\mathrm{n}$} & \multicolumn{4}{|c|}{ Parameter estimates } & \multicolumn{2}{|c|}{ Model statistics } \\
\hline & & & Intercept & SE intercept & Slope & SE slope & $\mathrm{p}$-Value & RMSE \\
\hline $\mathrm{C}_{14: 0}$ & $\%$ & 18 & 2.26 & 0.34 & -2.01 & 1.68 & $<.001$ & 1.13 \\
\hline $\mathrm{C}_{15: 0}$ & $\%$ & 18 & 2.49 & 0.32 & -2.70 & 1.38 & $<.001$ & 0.93 \\
\hline$C_{16: 0}$ & $\%$ & 18 & 22.7 & 2.51 & -18.1 & 8.38 & $<.001$ & 5.62 \\
\hline$C_{17: 0}^{100}$ & $\%$ & 18 & 1.45 & 0.27 & -0.858 & 0.702 & $<.001$ & 0.47 \\
\hline $\mathrm{C}_{18: 0}$ & $\%$ & 18 & 36.4 & 1.67 & -39.9 & 21.1 & $<.001$ & 14.2 \\
\hline $\mathrm{C}_{18: 2 \mathrm{n} 6}$ & $\%$ & 18 & 3.34 & 1.43 & 3.15 & 3.74 & 0.048 & 2.51 \\
\hline CLA & $\%$ & 18 & 0.74 & 0.22 & 0.471 & 1.03 & 0.009 & 0.69 \\
\hline $\mathrm{C}_{18: 3 \mathrm{n} 3}$ & $\%$ & 18 & 0.74 & 0.31 & 2.39 & 1.78 & 0.043 & 1.19 \\
\hline SFA & $\%$ & 18 & 75.4 & 5.33 & -28.1 & 27.3 & $<.001$ & 18.3 \\
\hline MUFA & $\%$ & 18 & 19.2 & 4.38 & 23.1 & 24.3 & 0.002 & 16.3 \\
\hline PUFA & $\%$ & 18 & 5.53 & 1.57 & 4.11 & 6.38 & 0.008 & 4.28 \\
\hline
\end{tabular}

Note: $\mathrm{CLA}=$ cis9, trans11 C18:2; SFA= saturated fatty acid; MUFA= monounsaturated fatty acid; PUFA= polyunsaturated fatty acid; $\mathrm{n}=$ number of treatment; $\mathrm{RMSE}=$ residual mean square error; $\mathrm{SE}=$ standard error.

otically with protozoa and takes advantage of the fauna. Therefore, any reduction of the protozoa population is expected to reduce methanogen as well and, probably, its methanogenesis activity. The ability of chitosan to decrease methanogen and protozoa populations is apparently related to its property for changing their cell permeability due to the interaction between polycationic chitosan and the electronegative charge on the microbial surface (Muxika et al., 2017). Supporting the argument, such a positive charge of chitosan is thought to be responsible for its antimicrobial activity through interactions with cell membranes with negatively charged microorganisms (Cazón et al., 2017). The decrease in total protozoa increases the total bacteria population in the rumen since protozoa possess predatory activity on bacteria in the rumen (Newbold et al., 2015).

This present study was in agreement with previous research which reported that increasing level of chitosan was associated with an increase of rumen $\mathrm{pH}$ (Goiri et al., 2009a; Goiri et al., 2009b; Goiri \& Oregui, 2014; Wencelová et al., 2013; Pereira et al., 2019; Li et al., 2013; Henry et al., 2015). However, there was a study reported that chitosan had no effect on rumen $\mathrm{pH}$ (Belanche et al., 2016a). Aranaz et al. (2009) thought that the possibility of chitosan could increase $\mathrm{pH}$ was due to physical hydrogels and ammonia gas, which neutralized $\mathrm{H}^{+}$in solution. Another theory that can explain the phenomenon is that formate may diffuse to rumen liquid phase to form $\mathrm{HCO}_{3}^{-}$and $\mathrm{H}_{2}$ and formation of the former product may increase the buffering capacity of rumen fluid (Leng, 2014). Concerning nitrogen metabolism, chitosan was reported to not affect rumen ammonia N concentration (Belanche et al., 2016a; Goiri et al., 2009a; Goiri et al., 2009b; Seankamsorn et al., 2019; Li et al., 2013; Henry et al., 2015). However, another study stated that chitosan increased ammonia levels in the in vitro rumen batch culture (Pereira et al., 2019). Chitosan is a nitrogenous compound that can be degraded in the rumen by microbes, so the higher concentration of ammonia in the chitosan diet is possibly due to amine group $\left(\mathrm{R}-\mathrm{NH}_{2}\right)$ conversion into ammonia (Beier \& Bertilsson, 2011). However, there was a study that stated that chitosan reduced the concentration of ammonia in the rumen (Goiri et al., 2014). The possibility of ammonia reduction is associated with a reduction in amino acid degradation through a mechanism of protection from ruminal degradation in a way that under the $\mathrm{pH}$ condition of the rumen, the positively charged $-\mathrm{NH}_{2}^{+}$groups of chitosan could interact electrostatically with the negatively charged carboxyl groups in amino acid (Chiang et al., 2009). In the latter case, the chitosan effect is likely similar to tannin that can protect the protein from degradation by rumen microbes (Kondo et al., 2014).

Belanche et al. (2016a) reported that the addition of chitosan to diets increased the proportion of propionate $\left(C_{3}\right)$ and decreased the proportion of butyrate $\left(C_{4}\right)$ in the rumen. Another study observed that the addition of chitosan increased propionate $\left(C_{3}\right)$ and valerate $\left(C_{5}\right)$ proportions, but decreased total VFA concentration, the proportion of acetate $\left(C_{2}\right)$, the ratio between acetate and propionate $\left(\mathrm{C}_{2}: \mathrm{C}_{3}\right)$, and BCVFA (Goiri et al., 2009a). Other studies also confirmed such an increase in the proportion of propionate and a decrease in the acetate proportion in the addition of chitosan (Goiri \& Oregui, 2014; Seankamsorn et al., 2019; Li et al., 2013). The proportion of VFA is greatly influenced by the ratio of forage and concentrate in the ration, microbial population structure in the rumen, long-chain fatty acids released from lipids, and many other end products resulting from microbial degradation from small components of the feed (Krehbiel, 2014). Such elevated propionate proportion by the addition of chitosan is apparently related also to the reduction of the protozoa population. It was reported that the defaunation of protozoa increased the molar proportion of propionate in the rumen and decreased the proportions of butyrate and acetate (Morgavi et al., 2010).

This present study was in agreement with previous research, which reported that adding chitosan in the whole soybean and sugarcane silage increased DMD, CPD, and NDFD (Gandra et al., 2016; Gandra et al., 2018). However, other studies reported conversely that the addition of chitosan reduced DMD in the in vitro rumen batch culture (Li et al., 2013; Wencelová et al., 2013). Some other studies even reported that chitosan addition had no effect on DMD, OMD, CPD, and NDFD (Henry 
et al., 2015; Pereira et al., 2019; Seankamsorn et al., 2019). In the present meta-analysis study, across all different experiments, chitosan was found to increase nutrient digestibility. Such an increase in the nutrient digestibility is apparently related to the alteration of microbial population structure following chitosan addition. Chitosan reduces the protozoa population, decreases predation intensity of protozoa on bacteria, and in turn, elevates the total bacteria population that greatly responsible for nutrient degradation and fermentation. Although chitosan has a broad spectrum anti-microbial property, apparently protozoa are generally more sensitive to the compound in comparison to those of rumen bacteria.

With regard to the influence of chitosan on fatty acid metabolism in the rumen, the current results supported the finding that chitosan reduced ruminal fatty acid biohydrogenation by simultaneously increasing the proportion of CLA and reducing $\mathrm{C}_{18: 0}$ regardless of the dietary fatty acid source (Goiri et al., 2010). Apparently, chitosan selectively inhibits microbial species involved in the lipolysis and biohydrogenation steps of fatty acids. Accordingly, there are three main groups of microbes involved, namely Anaerovibrio lipolytica that liberates fatty acids from their glycerol backbones, Butyrivibrio fibrisolvens that biohydrogenates PUFA to vaccenic acid, and finally Butyrivibrio proteoclasticus that plays a role in the terminal step of biohydrogenation, i.e., the conversion of vaccenic acid to stearic acid, the C18 saturated fatty acid (Jenkins et al., 2008; Lourenço et al., 2010; Toral et al., 2018; Vasta et al., 2019). A study of Belanche et al. (2016b) showed that chitosan addition at 5\% DM decreased the relative abundance of both Anaerovibrio sp. and Butyrivibrio sp. in the rumen simulation technique system, which was measured by employing the Next Generation Sequencing method. The result, therefore, indicates that chitosan may be used to modulate fatty acid metabolism in the rumen by elevating beneficial fatty acids for human health such as PUFA, omega 3 fatty acids, and CLA. However, their appearance in animal products requires further in vivo investigation.

\section{CONCLUSION}

Chitosan seems to be suitable for use as a feed additive in ruminant diets. Chitosan addition is able to mitigate enteric methane emission, alters rumen fermentation profiles toward a favorable direction, and improves nutrient digestibility. Further, chitosan plays a role in inhibiting biohydrogenation of fatty acids in the rumen as indicated by the increase of PUFA and the decrease of SFA.

\section{CONFLICT OF INTEREST}

Anuraga Jayanegara, Nahrowi, and Sri Suharti serve as editors of the Tropical Animal Science Journal, but has no role in the decision to publish this article. We also certify that there is no conflict of interest with any financial, personal, or other relationships with other people or organization related to the material discussed in the manuscript.

\section{ACKNOWLEDGEMENT}

We are grateful to Directorate General for Higher Education, Indonesian Ministry of Education and Culture, for providing "World Class Research" grant (year 2020) to the corresponding author, and Southeast Asian Regional Center for Graduate Study and Research in Agriculture (SEARCA) for providing PhD Research Scholarship to the first author.

\section{REFERENCES}

Aranaz, I., M. Mengibar, R. Harris, I. Panos, \& B. Mirrales. 2009. Functional of characterization of chitin and chitosan. Curr. Chem. Biol. 3: 203-230. https://doi. org/10.2174/187231309788166415

Beier, S. \& S. Bertilsson. 2011. Uncoupling of chitinase activity and uptake of hydrolyses products in freshwater bacterioplankton. Limnol. Oceanogr. 56:1179-1188. https://doi. org/10.4319/1o.2011.56.4.1179

Belanche, A., E. Ramos-Morales, \& C. J. Newbold. 2016a. In vitro screening of natural feed additives from crustaceans, diatoms, seaweeds and plant extracts to manipulate rumen fermentation. J. Sci. Food Agric. 96: 3069-3078. https:// doi.org/10.1002/jsfa.7481

Belanche, A., E. Pinloche, D. Preskett, \& C. J. Newbold. 2016b. Effects and mode of action of chitosan and ivy fruit saponins on the microbiome, fermentation and methanogenesis in the rumen simulation technique. FEMS Microbiology Ecology. 92: fiv160. https://doi.org/10.1093/femsec/fiv160

Cazón, P., G. Velázquez, J. A. Ramirez, \& M. Vázquez. 2017. Polysaccharide-based filmsand coatings for food packaging: a review. Food Hydrocoll. 68: 136-148. https://doi. org/10.1016/j.foodhyd.2016.09.009

Chiang, Y. W., T. H. Wang, \& W. C. Lee. 2009. Chitosan coating for the protection of amino acids that were entrapped within hydrogenated fat. Food Hydrocoll. 23: 1057-1061. https://doi.org/10.1016/j.foodhyd.2008.04.007

Gandra, J. E., C. S. Takiya, E. R. Oliveira, P. G. Paiva, R. H. T. B. Goes, R. S. Gandra, \& H. M. C. Araki. 2016. Nutrient digestion, microbial protein synthesis, and blood metabolites of Jersey heifers fed chitosan and whole raw soybeans. Rev. Bras. Zootec. 43: 130-137. https://doi.org/10.1590/ S1806-92902016000300007

Gandra, J. R., E. R. Oliveira, C. S. Takiya, R. H. T. B. Goes, P. G. Paiva, K. M. P. Oliveira, E. R. S. Gandra, N. D. Orbach, \& H. M. C. Haraki. 2016. Chitosan improves the chemical composition, microbiological quality, and aerobic stability of sugarcane silage. Anim. Feed Sci. Technol. 214: 44-52. https://doi.org/10.1016/j.anifeedsci.2016.02.020

Gandra, J. R., C. S. Takiya, T. A. Del Valle, E. R. Oliveira, R. H. T. B. de Goes, E. R. S. Gandra, J. D. O. Batista, \& H. M. C. Araki. 2018. Soybean whole-plant ensiled with chitosan and lactic acid bacteria: Microorganism counts, fermentative profile, and total losses. J. Dairy Sci. 101: 7871-7880. https://doi.org/10.3168/jds.2017-14268

Goiri, I., A. Garcia-Rodriguez, \& L. M. Oregui. 2009a. Effect of chitosans on in vitro rumen digestion and fermentation of maize silage. Anim. Feed Sci. Technol. 148: 276-287. https:// doi.org/10.1016/j.anifeedsci.2008.04.007

Goiri, I., L. M. Oregui, \& A. Garcia-Rodriguez. 2009b. Doseresponse effects of chitosans on in vitro rumen digestion and fermentation of mixtures differing in forage-toconcentrate ratios. Anim. Feed Sci. Technol. 151: 215-227. https://doi.org/10.1016/j.anifeedsci.2009.01.016

Goiri, I., G. Indurain, K. Insausti, V. Sarries, \& A. GarciaRodriguez. 2010. Ruminal biohydrogenation of unsaturated fatty acids in vitro as affected by chitosan. Anim. 
Feed Sci. Technol. 159: 35-40. https://doi.org/10.1016/j. anifeedsci.2010.05.007

Goiri, I. \& L. M. Oregui. 2014. Use of chitosans to modulate ruminal fermentation of a $50: 50$ forage-to-concentrate diet in sheep. J. Anim. Sci. 88: 749-755. https://doi.org/10.2527/ jas.2009-2377

Haryati, R. P., A. Jayanegara, E. B. Laconi, M. Ridla, \& P. Suptijah. 2019. Evaluation of chitin and chitosan from insect as feed additives to mitigate ruminal methane emission. In AIP Con. Proc. 2120, 040008. https://doi. org/10.1063/1.5115646

Henry, D. D., F. M. Ciriaco, \& M. Kohmann. 2015. Effects of chitosan on nutrient digestibility, $\mathrm{CH} 4$ emissions, and in vitro. J. Anim. Sci. 93: 3539-3550. https://doi.org/10.2527/ jas.2014-8844

Hristov, A. N., T. Ott, J. Tricarico, A. Rotz, G. Waghorn, A. Adesogan, J. Dijkstra, F. Montes, J. Oh, \& E. Kebreab. 2013. Mitigation of methane and nitrous oxide emissions from animal operations: III. A review of animal management mitigation options. J. Anim. Sci. 91: 5095-5113. https://doi.org/10.2527/jas.2013-6585

Janssen, P. H. 2010. Influence of hydrogen on rumen methane formation and fermentation balances through microbial growth kinetics and fermentation thermodynamics. Anim. Feed Sci. Technol. 160: 1-22. https://doi.org/10.1016/j. anifeedsci.2010.07.002

Jayanegara, A., K. A. Sarwono, M. Kondo, H. Matsui, M. Ridla, E. B. Laconi, \& Nahrowi. 2018a. Use of 3-nitrooxypropanol as feed additive for mitigating enteric methane emissions from ruminants: a meta-analysis. Ital. J. Anim. Sci. 17: 650-656. https://doi.org/10.1080/1828051X.2017.1404945

Jayanegara, A., R. P. Harahap, R. F. Rozi, \& Nahrowi. 2018b. Effects of lipid extraction on nutritive composition of winged bean (Psophocarpus tetragonolobus), rubber seed (Hevea brasiliensis), and tropical almond (Terminalia catappa). Vet. World. 11: 446-451. https://doi.org/10.14202/ vetworld.2018.446-451

Jenkins, T. C., R. J. Wallace, P. J. Moate, \& E. E. Mosley. 2008. Recent advances in biohydrogenation of unsaturated fatty acids within the rumen microbial ecosystem. J. Anim. Sci. 86: 397-412. https://doi.org/10.2527/jas.2007-0588

Kaharabata, S. K., P. H. Schuepp, \& R. L. Desjardins. 2015. Estimating methane emissions from dairy cattle housed in a barn and feedlot using an atmospheric tracer. Environ. Sci. Technol. 34: 3296-3302. https://doi.org/10.1021/ es990578c

Kondo, M., Y. Hirano, N. Ikai, K. Kita, A. Jayanegara, \& H. O. Yokota. 2014. Assessment of anti-nutritive activity of tannins in tea by-products based on in vitro rumen fermentation. Asian Australas. J. Anim. Sci. 27: 1571-1576. https:// doi.org/10.5713/ajas.2014.14204

Kong, M., X. G. Chen, K. Xing, \& H. J. Park. 2010. Antimicrobial properties of chitosan and mode of action: a state of the art review. Int. J. Food Microbiol. 144: 51-63. https://doi. org/10.1016/j.ijfoodmicro.2010.09.012

Krehbiel, C. R. 2014. Invited Review: Applied nutrition of ruminants: Fermentation and digestive physiology. Professional Animal Scientist. 30: 129-139. https://doi. org/10.15232/S1080-7446(15)30100-5

Leng, R. 2014. Interactions between microbial consortia in biofilms: a paradigm shift in rumen microbial ecology and enteric methane mitigation. Anim. Prod. Sci. 54: 519-543. https://doi.org/10.1071/AN13381

Li, C., X. Zhao, Y. Cao, Y. Lei, C. Liu, H. Wang, \& J. Yao. 2013. Effects of chitosan on in vitro ruminal fermentation in diets with different forage to concentrate ratios. J. Anim. Vet. Adv. 12: 839-845
Lourenço, M., E. Ramos-Morales, \& R. J. Wallace. 2010. The role of microbes in rumen lipolysis and biohydrogenation and their manipulation. Anim. 4: 1008-1023. https://doi. org/10.1017/S175173111000042X

Morgavi, D. P., E. Forano, C. Martin, \& C. J. Newbold. 2010. Microbial ecosystem and methanogenesis in ruminants. Anim. 4: 1024-1036. https://doi.org/10.1017/ S1751731110000546

Muxika, A., A. Etxabide, J. Uranga, P. Guerrero, \& K. de la Caba. 2017. Chitosan as a bioactive polymer: Processing, properties and applications. Int. J. Biol. Macromol. 105: 1358-1368. https://doi.org/10.1016/j.ijbiomac.2017.07.087

Newbold, C. J., G. de la Fuente, A. Belanche, E. RamosMorales, \& N. R. McEwan. 2015. The role of ciliate protozoa in the rumen. Front. Microbiol. 6: 1-14. https://doi. org/10.3389/fmicb.2015.01313

Patra, A. K. \& J. Saxena. 2011. Exploitation of dietary tannins to improve rumenmetabolism and ruminant nutrition. J. Sci. Food. Agric. 91: 24-37. https://doi.org/10.1002/jsfa.4152

Pereira, D. C., R. H. T. B. Goes, A. C. Martinez, J. R. Gandra, E. Presendo, M. V. Santos, R. T. Oliveira, N. G. Silva, M. G. Ribeiro, \& J. L. R. Alvez. 2019. In vitro evaluation of the association of chitosan and cashew nut shell liquid as additives for ruminants. Rev. Bras. Saúde Prod. Anim. 20: 1-12. https://doi.org/10.1590/s1519-994005102019

Seankamsorn, A., A. Cherdthong \& M. Wanapat. 2019. Combining crude glycerin with chitosan can manipulate in vitro ruminal effciency and inhibit methane synthesis. Anim. 10: 30. https://doi.org/10.3390/ani10010037

St-Pierre, N. 2001. Integrating quantitative findings from multiple studies using mixed model methodology. J. Dairy Sci. 84: 741-755. https://doi.org/10.3168/jds. S0022-0302(01)74530-4

Toral, P. G., F. J. Monahan, G. Hervas, P. Frutos, \& A. P. Moloney. 2018. Modulating ruminal lipid metabolism to improve the fatty acid composition of meat and milk challenges and opportunities. Anim. 12: S272-S281. https://doi. org/10.1017/S1751731118001994

Vasta, V., M. Daghio, A. Cappucci, A. Buccioni, A. Serra, C. Viti, \& M. Mele. 2019. Plant polyphenols and rumen microbiota responsible for fatty acid biohydrogenation, fiber digestion, and methane emission: Experimental evidence and methodological approaches. J. Dairy Sci. 102: 37813804. https://doi.org/10.3168/jds.2018-14985

Vendramini, T. H. A., C. S. Takiya, T. H. Silva, F. Zanferari, M. F. Rentas, C. E. C. Consentini, R. Gardinal, T. S. Acedo, \& F. P. Rennó. 2016. Effects of a blend of essential oils, chitosan or monensin on nutrient intake and digestibility of lactating dairy cows. Anim. Feed Sci. Technol. 214: 12-21. https://doi.org/10.1016/j.anifeedsci.2016.01.015

Wencelová, M., Z. Váradyová, K. Mihaliková, S. Kišidayová, \& D. Jalč. 2013. Evaluating the effects of chitosan, plant oils, and different diets on rumen metabolism and protozoan population in sheep. Turk. J. Vet. Anim. Sci. 38: 26-33. https://doi.org/10.3906/vet-1307-19

Wina, E., S. Muetzel, \& K. Becker. 2005. The impact of saponins or saponin-containing plant materials on ruminant production - a review. J. Agric. Food Chem. 53: 8093-8105. https://doi.org/10.1021/jf048053d

Zanferari, F., T. H. A. Vendramini, M. F. Rentas, R. Gardinal, G. D. Calomeni, L. G. Mesquita, C. S. Takiya, \& F. P. Rennó. 2018. Effects of chitosan and whole raw soybeans on ruminal fermentation and bacterial populations, and milk fatty acid profile in dairy cows. J. Dairy Sci. 101: 10939-10952. https://doi.org/10.3168/jds.2018-14675 